\title{
Islamic Images and Terminology Used in the Western Media
}

\author{
Bashy Quraishy
}

\section{ABSTRACT}

\begin{abstract}
Most societies in Western World has formulated a premature assumptions toward Islam due to the negative depictions of Islamic world doing by Western media which focused mainly on the issues of terrorism, intolerance, poverty, conflicts, fanaticism, horrible disease, low life qualities among Islamic countries, backwardness and lack of progress. This article explores and describes some statements made by Western media (as well as Western journalists), along with events as the setting of such comments. In order to overcome such situations, media monitoring must be professional and constant. Those who concern with the misleading information toward

Islam must provide clear, short, and well-written press releases at regular intervals. Another suggestion is by drawing attention of ethnic youth toward journalism as noble profession and good trade.
\end{abstract}

Kata kunci: Islamic images, western media, journalism

The role and power of media in spreading information in a modern society is awesome. Once an information - right or wrong, manufactured or factual goes out to public, it creates its own rhythm. One can retreat, amend, or correct it but you can not nullify it. A word spoken, written or heard has its own magic and life. In public discussions and in this atmosphere of xenophobia, anti-Semitism, Islamophobia, and national chauvinism, there is very little space for different religious identities or balanced media coverage relating to non-Christian faiths, especially Islam.

\section{Documentation and Surveys}

To get a sense of the enormity of the subject, I went to Google Search Machine and entered "Is- lam in the Western Media". In less than 0.9 seconds, I got a list of 836,000 articles. Under the headline," Western media, prejudices and Islam" there are 16,800 articles.

In the last many years, MediaWatch, has collected over twenty thousands news paper cuttings and TV news - from the Danish, the European, and the international media.

Our research clearly documents that nearly $65 \%$ of the media coverage relating to ethnic and religious minorities in the West, the situation in the developing countries, non-European cultures especially from the Middle East and last but not the least, the general description of Islam, is negative. By negative, we mean the way non-Western countries and people are depicted and how the over all focus of news coverage is always on pov- 
erty, backwardness, conflicts, fanaticism, sectarian killing, horrible diseases, catastrophes, and lack of progress.

After the fall of the Soviet Union, the demonizing of Islam, as a religion and its followers as a bunch of lunatic fanatics has been very obvious in most of the Western media. According to an article published in the student newspaper Daily Texan at the University of Texas - Austin, the author Pricilla Martinez writes:

"The media have been primary contributors to an erroneous image of Islam by stereotyping all Muslims as being fundamentalists or terrorists. For example, after the February 26, 1995 bombing of the World Trade Center, the media depicted American Muslims, in general as the cause of disaster. With circumstantial evidence, the media accused, indited, tried and found the alleged fundamentalists, thus All-American Muslims, guilty."

This trial by the media has accelerated after $11^{\text {th }}$ September 2001 terrorist attacks on USA and the start of the Iraq conflict.

The Dutch sociologist and journalist, Dr. Corneilis Hulsman who lives in Egypt and publishes the magazine, Arab-West Report, visited Islamic Christian study Center in Copenhagen in November 2004. In his lectures at the Center and at the University of Copenhagen, he described the media coverage of Islam in the West, as very unfortunate. "Think if the Muslims accuse the Christianity for being Nazist because of what Hitler did in the second World War or because of the actions of few new Nazis today."

The Western media, according to Dr. Hulsman, regularly presents the sporadic local conflicts between Egyptian Christian Coptic minority and the Muslim majority as conflict between two religions. The media does not hold back, in not only taking the side of the Coptic but also manufacturing stories to suite their angel.

Although there have been a great deal of interest and research done by the experts to find the reasons behind this unbalanced media coverage, the study done by the American scholar, Steven Hoffman is very telling. In his book, Islam and democracy - micro level indicators of compat- ibility, he is very critical of the way, media ferments a biased picture of Islam. He says:

"Journalists are not interested in good stories but stories with an angel. Behind media, there are powerful lobbies who need conflicts, polarization and misinformation to sell their products."

Journalist, H. D. S. Greenway writes in the International Herald Tribune of $6^{\text {th }}$ march 2004:

"Certainly journalism is suffering from the demand for instant news. One expects it from $\mathrm{CNN}$ or The Associated Press, which traditionally deal in breaking stories, but newspaper correspondents, who once had a bit of a time to reflect before they wrote, are now being asked to feed their web sites at all hours of the day. According to ABC's Ted Koppel, the demands of instant journalism mean reporters "rarely have time to go out and do any reporting. They are almost chained to that satellite relay point."

Media monitoring projects in diverse countries in Europe and in USA, the qualitative analysis report from the European Day of Media Monitoring in November 2003, done by Jessika ter Wal, from Utrecht University, the survey regarding Islamophbia done by EUMC, Runnymead Trust's reports on Islamophobia and Fair Play's report on "Islam in the Western Media" are some of the work done on the subject of media coverage of Islam in the West.

To illustrate, how the Western media uses specific images, misleading headlines, and xenophobic linguistic terminology to report events, set the political agenda and wage ideological war, we have selected three recent examples.

- Indonesian President's speech $\left(20^{\text {th }}\right.$ October 2004).

- Death of 86 Thai protesters with Muslim background $\left(27^{\text {th }}\right.$ October 2004).

- Killing of the Dutch Filmmaker, Theo Van Gogh -3 November 2004

\section{Coverage of Indonesian President's Speech 20 ${ }^{\text {th }}$ Oct 2004}

At noontime, on $20^{\text {th }}$ October 2004, BBC World Service in its News Bulletin presented a live TV 
Program from Jakarta where the newly elected President of Indonesia, Mr. Susilo Bambang Yudhoyono was being sworn in.

BBC's Anchorwoman, Lucy Hawkins said:

"The new Indonesian President has pledged to deal with corruption, nepotism, and Islamic terrorism”.

The word Islamic was, however, dropped when Ms Hawkins interviewed Mr. Michael Hithcock in the same news item. But in latter hourly news, it was again reintroduced.

Since to cross check the validity of such news, MediaWatch often records other TV Channels, we turned to CNN and Danish TV Stations. It turned out that not only other channels did not mention Islamic terrorism, but also the President himself never used this term. Even on BBC's own Web Site that day, there was only the mention of terrorism. The same was true for $\mathrm{CNN}$ web page.

On the basis of this simple test, MediaWatch, on $21^{\text {st }}$ October 2004, wrote to BBC World Service in London and put two explanatory questions.

- Why BBC inserted the word Islamic in connection with terrorism in its news bulletin?

- What was BBC's official policy in correctly referring to the sources, in this case the President of Indonesia?

Until today, MediaWatch has not heard anything from $\mathrm{BBC}$.

$\mathrm{BBC}$ has, for years, claimed to be neutral in its coverage, but the Muslim communities, all across the globe are increasingly skeptical of this claim as well as, of other Western news production regarding Islam, the Muslim people and the Muslim World at large.

For the record, MediaWatch wishes to mention that this incident is not the first time, $\mathrm{BBC}$ has added the word Islamic while referring to terrorism.

\section{Death of 84 Thai Protesters with Muslim Background 27 October 2004}

Looking at the Danish and international media, the news was headlined in different fashion but the word Muslim was repeatedly used.

- Financial Times wrote: "Civil Unrest - Seventy eight Thai Muslims suffocate in army trucks."

- One of the largest Danish Daily, Politiken headlined: "Unrest in Thailand - 84 demonstrators strangled and shot."

- MetroXpress - the largest circulated, free newspaper in Denmark said: "Mutiny in Thailand accelerates - 84 Muslim mutineers killed in military's arrest after demonstration."

- Another large Danish free newspaper, Urban used this headline: " 84 Muslim killed after the demonstration."

\section{Killing of the Dutch Filmmaker, Theo Van Gogh 3 November 2004}

The most recent tragic killing of the Dutch filmmaker, Theo Van Gogh, at the hands of a young Dutch man with Moroccan roots was covered in many different ways, with a very distinct focus on Islam.

- News UK, 3 November 2004: "Dutch filmmaker, with controvercial views on Islam, shot dead."

- The Guardian - UK, 3 November 2004: "Controversial Dutch film director shot dead in street."

- International Herald Tribune, 3 November 2004: "Islam critic slain in Amsterdam."

- International Herald Tribune, 4 November 2004: "Dutch arrest 8 Islamists in Van Gogh killing."

- Financial Times, 5 November 2004: "Dutch plan crackdown on suspected Islamic extremists."

- The Economist, 6 November 2004: "The Nederlands was convulsed by the murder of a film director."

- Le Soir of Belgium, 7 November 2004: "Menace islamiste sur la Hollande."

- Looking at the 2 largest Danish national newspaper, one can read: Politiken, 5 November 2004: "Eight held after religious murder. The man who is suspected for the murder of the Dutchman had contact with international Muslim terror groups."

In its editorial, however, the tone was more cautious. It asked for cool headedness and explained "The fight is not between Muslims and Christians but between fanatics and moderates".

- The other newspaper Berlingske headlined: "Re- 
ligious motives being looked at after the beastly murder."

In its editorial, the newspaper wrote: "This killing is a bloody expression of a clash of cultures, which is underway in Western Europe these days."

In MW's opinion, this kind of misleading headlines and a misplaced focus on Islam, is not only harmful to inter-ethnic relations but also against all codes of journalistic ethics. Luckily, not all journalists subscribe to sensational headlines.

The only newspaper, which did try to analyze the background of the whole event for its readers was. The Guardian. On $4^{\text {th }}$ November 2004, in a full length interview with the Somali born, Ayaan Hersi Ali, a politician and member of the Dutch parliament for a right wing party VVD and who has written the script of the movie, "The submission", the journalist explained what kind of filthy and provocative language Ms. Ali and Mr. Van Gogh have been using to describe Prophet Muhammad, Islam and the Muslims. Guardian described in graphic language that:

"Ayaan Hirsi Ali has called the prophet Muhammad a "lecherous tyrant, a pervert", Islam a "backward religion", and the Quran "in part a licence for oppression". Theo van Gogh dubbed Muslims "goat-fuckers", a radical Islamic leader "Allah's pimp", and Islam a "retrograde and aggressive" faith".

Guardian also touched upon the issue of freedom of speech and the response it can unleash. The paper wrote:

"In the midst of this tinderbox, insisting on their right to speak freely and with the support of many Dutch people, Hirsi Ali and Van Gogh scattered their sparks - a blistering critique of Islam - with magnificent disregard for the feelings they might be offending.

Damning Islam as a "backward, 12th- century religion", a "medieval, misogynist cult incapable of self-criticism and blind to modern science".

One of the most respected Swedish author, Jan Guillou who has penned many best selling novels including The Crusaders told of an interesting experience to the Danish newspaper, Chris- tian Daily on 13 November 2004. While researching for material, he was stranded in Kazakhstan. In 48 hours, he watched CNN and Fox News in a hotel room. Every time a Muslim person was shown on TV, he noted it under bad guy or good guy category. In 48 hours, there was 57 mentions of Muslims. Accrding to Mr Guillou, all Muslims were shown as bad guys - jumping like crazies with Kalashnikovs in their hands, throwing stones or burning Israeli and American flags. All women shown on TV wore headscarves.

Jan Guillou was so upset at this anti-Islam media propoganda that he has decided to confront this demonizing of Muslims for the rest of his life.

\section{Media Knows Its Power}

The rejection of any thing non-European and Christian has stifled the debate, thus has resulted in the polarization of the society. Consequently the tolerance level of the population, vise-vies the Muslim ethnic minorities have dramatically dropped. Genuine acceptance of foreigners is now missing. Weather these other people differ in thinking, color of skin, or sexual orientation has no bearing on this attitude.

Looking at, most of the Western media, one can notice that often the pictures and headlines have no relation to the story. Contents of the articles or stories may be positive or neutral but are garnished with stereotyped language and images.

\section{Use of Negative Terminology}

Primitive, fundamentalist, Islamist, extremist, intolerant, authoritarian, militant, medieval, women oppressive, radical, menacing, aggressive, patriacal, backward, tyrannical, and lacking the will to reform itself, are some of the adjectives used liberally in front of or after the word, Islam.

More recently, one hears or reads such terms as, Militant Islam, Islamist, fundamentalist Imams, Radical Islamic Clerek, Jehadist movements, Fascio-Islam, and Quran-fascism. Even Nazism and Communism are being compared with Islam. One member of the Danish parliament even bombasti- 
cally declared that Islam is like Hitler in an interview in the largest circulated weekly newspaper in Denmark, Søndagsavisen.

This general description of Islam as a religion is very insulting, derogatory, and provocative to most Muslim communities. They welcome criticism of individuals, groups, or even whole societies where Islam is the major religion but draw the line between Freedom of speech and Freedom of hate speech.

Connecting individual acts of violence, committing of crime, lack of integration or not conforming to the customs of the host society, to the faith itself, not only irritates most followers of Islam but puts majority of law abiding, peaceful and well integrated members of diverse Muslim groups in the West, in a very difficult position.

The Western media has failed to report, the struggle between good and bad, tolerance and intolerance, orthodex and moderate that goes on within Islam as well as around it. The efforts of liberals in Islamic communities world over, are not helped by the tendency of non-Muslims to behave as if the only voices of Islam that mattered, were of the reactionaries.

It has not gone un-noticed, among most Muslims that the amount of the negative media coverage and debate they suffer, is missing when it comes to Catholicism, born- again Protestantism, hard-core Hinduism, orthodex Judaism or any other world religion.

\section{Some Comparative Examples}

Besides the negative description of Islam, there are other interesting phrases used deliberately by the Western media:

- Afghan tribal chiefs are routinely termed as War Lords.

- In the first Gulf war of 1991, comparesion of Iraqi soldiers and Allied forces was described as our boys and their soldiers, our military vehcles and their armoured tanks (Guardian - UK, 23 January 1991).

- In the second Gulf war of 2004, it looked like this - our liberation forces are fighting the in- surgents, rebels, and Jihadist.

- The Civilised World condemns terrorism.

- USA is called, the leader of the Free World.

- American Baseball games are dubbed as World Series.

- The western democratic way of life-

- They hate our humanistic values -

- Documents like British Magna Charta, American Bill of Rights and the struggle for human rights under the French Revolution, are always refered to as first in the world

The notion of the world outside the Western areas, seems to be absent in the mindset of most people living in Europe, USA, or even Australia.

\section{Keeping the Diasporic Identity Alive}

Most societies in Europe not only demand unquestioned loyalty from diverse ethnic minority groups among Islam, but also submission to the "idea" of a common identity - mostly determined and formulated by the majority.

This unwelcome insistence creates conflicts and a sense of alienation among most Muslim groups who come from non-European hemisphere. These groups have a strong sense of their own identities, which are often constructed by a very long historical process, cultural embedding, and religious practices. For them, the question of changing, altering or totally adopting the host identity is a non-starter. Of course, they wish to be part of the society they live in, but as equal and not as junior partner.

In this endeavor, ethnic minority media has always played a rescuing part - not only to provide information, not covered by the mainstream media, but also to preserve home lands languages, cultures, traditions, religious practices, and fostering a sense of belonging.

As the concept of multiculturalism has failed to fulfill the needs of all segments of the society, the role of ethnic media is becoming clearer. With the advancement of technology, internet, satellite dish, and increasing professionalism, ethnic minority groups are able to keep their diasporic identities alive. Some people will argue against this 
trend, but I believe, in light of European cultural arrogance, this step is not only inevitable but also necessary. It is high time that the European identity is redefined and re-polished - keeping in mind the new realities.

\section{Violence Has no Religion!}

In International Herald Tribune of $25^{\text {th }}$ June 2004, there was a very interesting and thought provoking news.

"Election force in Latin America. Disillusioned with democracy, the poor turn to violence"

This headline describes a factual situation which has been very prevelent throughout the world. Unfortunately, violence in the face of powerlessness, often becomes the only tool available to those who feel and experience oppression in the societies.

Palestine, Sri Lanka, Kashmir, East Timor, Colombia, Peru, Afghnistan, Ireland, Sudan, Chechnia, and now Iraq are some of the visible examples of such hot spots.

When the Western media covers those conflicts where Islam is not dragged in, religion is never mentioned as the root cause or the instigator of the violence. Non-Muslim conflicts are described as socio-economic issues, political differences or at best, left wing rebel movements fighting for their rights or independence.

But when it comes to the areas where Muslim minorities are taking to fighting back oppression, this response is quickly dubbed as "Islamic terrorism",'Muslim Militancy"., Fundamentalistic terror", ,Islamic barbarism"," Jihady struggle", ,AlQaeeda connection", etc.

The suicide bombing is being described as the new tool of "Islamic fanatics, who hate the Western style of life".

\section{Why All these Labels on Islam?}

The Muslim communities are justified to ask: "Why no relgious labels were used when a Tamil Hindu girl, assasinated the Indian Prime Minster, Rajiv Ghandi by a suicide bomb in 1989 or when two Sikh body guards of Indira Ghandi shot her in cold blood? What about the killings and bombings in, Ireland, Korsica, Basque region of Spain, Columbia, Peru, and Rawanda? In these conflicts, Christians are killing other Christians.

On whose name. One might ask?

It seems that a large part of the Western media, intellectuals and the political establishment are determined to connect, the second largest religion in the wotld - Islam- with every horrible act, the civilized people every where, would and should abhor and condemn.

\section{Political Signals}

Politicians also play a vital role in spreading hatred against Islam, through media.

On $10^{\text {th }}$ April 2000, Chairman of the Danish

People's Party, Pia Kjærsgaard said on Danish TV: "Most immigrants today are from Third World countries. And many of them are Muslims who have absolutely no intention of becoming part of 'Danishness'... They despise whatever is Western, Danish or Christian. They often come with baggage full of male chauvinism, ritual slaughtering, circumcision of girls and clothes that oppress women and with their traditions which belong to the Dark Middle Ages."

The journalist never asked her any critical question.

On $29^{\text {th }}$ October 2002 in DR-Radio, Minister for Integration, Mr Bertel Haarder said:

"It is the people from the poor countries, those from Third World countries, from non-Western countries who are the problem. They have a low productivity, a low degree of education, bad language skills, and they arrive in a country with the world's highest minimum wages - which they have difficulty deserving - and with the world's highest social security, which for most of them, makes it a bad business for them, to go to work. And then it has to end up wrongly, and it does end up wrongly."

Mr Haarder is used to such statement without any intervention from the journalists.

These statements and many more of these types are uttered on daily basis in Denmark and the rest of Europe.

Soon after, the murder of Theo Van Gogh and 
the capture of the suspect, after a shoot out with police and who was in a prison hospital with gunshot wounds, the Dutch justice minister, Piet Hein Donner, said:

"He acted out of radical Islamic fundamentalist convictions".

The freedom of speech is often mentioned whenever, Muslim Communities challenge anti-Islam utterances but it would be worth while to remember the words of the late Swedish Ombudsman for Ethnic Discrimination, Margareta Wadstein while discussing media coverage:

"Everybody has prejudices, but only by facing them, can we fight them."

\section{Why the Misleading Coverage?}

There are many reasons as to why most journalists indulge in un-researched and semi-professional writings about Islam. The situation is improving slowly but still, there is a long way to go.

Among the abvious reasons, one can name:

- Ideological upbringing and ethno-centric education system.

- Ignorance of non-European cultures, religions and ways of living.

- Deadline pressure from the management and editorial interference.

- Economic interest of the employers and neck breaking competition.

- Cultural arrogance prevailing in the societal discussions.

- Lack of propmt and quick response from the victims of media manipulation.

- Lack of co-ordination among Muslim communities and non-use of consumer power tool.

But, what ever way, the media looks at the issue, the journalists have to keep in mind that their actions have profound effects on public's perception of Islam and the whole process of integration. A small part of the media world is critical of the way, mainstream media handles the issues relating to ethnic minorities, especially people of Muslim faith.

In May 2004,journalists at the Daily Express in UK did refuse to write anti-asylumseekers stories against the will of the editors, the journalists at the Danish newspaper Politiken, have standing order to refrain from using the derogatory words about Islam, the top management at the International federation of Journalists in Brussels has cooperated in holding press meetings to talk about media and minority issues. Many journalist unions in EU have established codes of conduct and diverse ethnic relations committees to raise awareness among its members.

\section{Consequences of Unbalanced Media Coverage}

- Conflict between diverse groups of Muslim communities and the societies they live in.

- Mutual integration has been derailed.

- Racial, ethinc and religious discrimination has increased dramatically.

- Media coverage is being used by political parties to put in place stricter immigration and asylum laws.

- Increase in ethnic media outlets - especially local and international TV channels from homelands.

- Un-professional journalism is effecting the quality in mainstream media.

- Militancy among ethnic populations especially the youth is on the rise.

- Financial loss to mainstream media

- Perpetuation of diasporic identity among ethnic and religious groups.

\section{Why Media Watching is Necessary?}

As the media has become more and more sophisticated and commercial over the last many years, it has become important for the victims of media manipulation, to live up to this daunting challenge. Today there are many groups trying to bring media's power to misinform to the attention of the public.

Those who work with and against media distortion of information, know that media in general has become the $4^{\text {th }}$ State power. Politicians, authorities, civil servants, and even the common 
man on the street is afraid of the power, journalists have at their disposal.

This state of affairs has made most of the journalists extremely protective of that power, which the society has bestowed on them. Most of them have developed very large egos, which need constant massage and appeasement.

Professionalism, documentation, analysis and distribution of information concerning media's portrayal of minorities, (ethnic, cultural, and religious), developing countries, migration issues, and asylum will give minorities a better access to media world.

\section{Suggestions for NGO to Counter the Situation}

- Media monitoring must be professional and constant.

- Provide clear, short and well written, press releases at regular intervals.

- Draw the attention of ethnic youth towards journalism as a profession. Convince parents and youth that journalism is a noble and good trade

- Show visibility by participating in media discussions on a professional level, not only on ethnic questions but also issues of common interests to the society. Answer back and comment what you find incorrect but the response must be target oriented.

- Arrange courses for members to empower them with knowledge, give them tools to formulate their views and most important of all, encourage them to speak up. Invite critical journalists to speak.

- Establish better contacts with those journalists who are willing to listen and invite media to hold discussions, seminars, conferences with NGO's on topics relevant to both minorities and the media.

- Send the journalists a list of names of contact persons from different ethnic groups which can give their opinion if need be. It will save the journalists time and they will use this source often. This list should contain important, qualified and competent resourse persons among NGOs to be used by the media as resources.

- Part information to the media. Many journalists are not used to inter-cultural, inter-ethnic and inter-religious thinking.

- Start a "Study Group" to document, analyse and look at the media mistakes. Provide such data to journalists so that they can study it and hopefully use it.

- Do not forget to compliment if you see a good TV programme, a well-researched article or even an informative radio programme. If criticism has to be dished out, this must be done in the bounds of reason, politeness and on factual basis.

- NGO's and ethnic minorities now have a good possibility of supporting the present network of alternative media on the internet, establishing their own topic oriented websites and e-mail chain letters

- Many European countries have grassroots TVChannels where local programmes can be made both in ethnic languages and host country's national language. Such TV programmes are public funded.

NGOs have to come to terms with the fact that in this age of fast information, it is their duty to get their message across. Media can live without them but they can not afford to ignore the importance of media's power.

Instead of constantly complaining, it would serve them well to co-operate, educate and make alliances with journalists. Influence is never served on a platter but is a hard won currency.

Speech at the International Seminar - Ljubljana Slovinia

Empowering minorities in the media in Multicultural societies, 12-13 November 2004 